\title{
Implementation of Self-Reliance Politics in Fishery Sector, Foreign Direct Investment, and Trawl Elimination: Dilemma Between Fulfilling Needs for Fish and Improving Fisherman Welfare
}

\author{
Sutejo K. Widodo*, and I. Indriyanto \\ Department of History, Faculty of Humanities, Diponegoro University
}

\begin{abstract}
This study aims to discuss the dilemma between the fulfillment of needs for fish and the improvement of fisherman welfare in Java, specifically in Pekalongan Municipality. It focuses on the dilemma occurring on the implementation of self-reliance politics policy in 1961, implementation of FDI (Foreign Direct Investment) policy in the fishery sector in 1969, and implementation of trawl elimination in 1980. To reveal these problems, the researchers used historical method, based on the government policy contained in the decree, agency reports, and agency bulletins. The research results find a dilemma between an effort to fulfill the needs for fish by increasing the catch production and an effort to improve the fisherman welfare.
\end{abstract}

Keywords: Self-reliance, Foreign Direct Investment; Tawl; Dilemma.

\section{Introduction}

This research discusses the implementation of self-reliance (Berdikari) policy of the fishery sector, Foreign Direct Investment (FDI), and trawl elimination, which has dilemma between fulfilling needs for fish and improving fishermen welfare. The concept of Self-reliance economy was formulated in 1961 of Old Order era, FDI in 1969, and trawl elimination in 1980 during New Order era. Although Java Island was surrounded by territorial waters, in the past in meeting the needs for fish, mainly sea fish, it was mostly done by bringing in the fish caught by fishermen from other regions or imported, in the form of salted fish and dried fish. This factor underlies the self-reliance policy, in which the fulfillment of the needs is gradually carried out in a self-sufficient manner with the establishment of self-reliance policy.

With the ban on fish import, the catches of Javanese fishermen continued to increase, and in line with the Foreign Direct Investment Law 1969, the catches continued to increase and were even able to export. However, the use of such massive trawl caused conflicts between

* Corresponding author: sutejokw@lecturer.undip.ac.id 
fishermen, and then the trawl was eliminated based on the Presidential Decree No. 39/1980. This is an interesting topic and needs to be explored and found its root problem to be reconstructed in the span of 1961 to 1980 .

The effort to meet the needs for fish in Java and effort to improve the fishermen welfare faced dilemma. The elimination of monopoly with the self-reliance policy was intended to improve the fishermen welfare, but the political concept of self-reliance was faced with the strong economic practices of Chinese ethnic fisheries that had been running for a long time. Then with the FDI in the fishery sector, the fishing business was developing rapidly, but on the other hand, it created gaps between fishermen so that the trawl was eliminated. From these problems, in this research three problems were then formulated: first was how the selfreliance policy in the fishery sector was politically and economically practiced, second was how the implementation of FDI policy in the fishery sector, and how the policy and implementation of trawl elimination was, by taking local level cases of Pekalongan region, Central Java.

To obtaining the overview on the fulfillment of the needs for fish and improvement of fishermen welfare that took place in the implementation of the self-reliance political policy in 1961, between the political concept and the strength of the longstanding ethnic Chinese economic business group, the implementation of FDI policy in the fishery sector in 1969 which urged the local fisherman business, and implementation of trawl elimination in 1980, as a policy to protect small fishermen.

\section{Method}

It was research with policy studies in the past, using historical methods with stages as follows: (1) source collection (heuristic), in the form of contemporary reports from the Indonesian Fisherman Cooperative Parent, Gemah Ripah magazine, Presidential Decrees, Government Regulations, Decrees, and Circular Letters, (2) studying the sources obtained to obtain valid and credible information, (3) interpreting the data and information, (4) making a description into explanation as an overview that followed the chronological elements that took place in a causal relationship.

\section{Literature Review}

Sea as a profitable resource was discussed by D.H. Cushing in The Provident Sea (1988) talking about the fishing activities in the North Atlantic and Pacific North America, before and after the fishing industry. Simple fishing gear was used before industrialization. With the development of fishing techniques, migrant fishermen from China had a substantial contribution. Chinese fishermen developed fishing gears and fishing techniques that produced large amounts of fish. The relation to the development of fishing technology in Indonesia was that the role of Chinese fishermen had some similarities with the discussion stated by Chusing [1].

Mc. Evoy [3] discussed the development of fishery in California for 130 years, in The Fishermen: Problem Ecology and Law in The California Fisheries 1830-1980 (1986), and analyzed public policy with ecological and historical approaches. This work discussed the overall sustainability of the fishery business. The importance of increasing fishing catches by fishermen often ignored the conservation efforts. The damage to the fishing environment which was detrimental to small fishermen encouraged the trawl elimination.

Raduan [4] Dari Pemungutan Tripang ke Penundaan Udang: Sejarah Perkembangan Perusahaan Perikanan di Borneo Utara, 1750-1990 (1995), discussed the sea as a resource that provided commodities for trade among nations. Marine resources became the principle 
of wealth and collapse for the Zulu kingdom, but this sector in the colonial and post-colonial periods was marginalized by policies based on land. Meanwhile, the management of fisheries was only carried out by a small department under the Ministry of Agriculture. The policies that marginalized the fishery business had several similarities with those occurring in Indonesia. However, in Indonesia, fishery commodities were intended to meet the domestic needs. Java Island with its large population was the main market of marine commodities.

Masyhuri [2] in a book entitled Menyisir Pantai Utara, Usaha dan Perekonomian Nelayan di Jawa dan Madura 1850-1940 (1996), described the fishery sector experiencing "deindustrialization" marked by the absence of fishing effort balance in Java and Madura with the rate of demand for salted fish consumption (p. 314). There was no significance between consumption and development of fishing technology on the north coast of Java, even until the 1960s. One important factor causing the process was the government's policy in fulfilling the consumption by importing or bringing in fish caught by fishermen from other areas such as Bagansiapi-api.

\section{Result and Discussion}

\subsection{Policy on Self-Reliance Economy in Fishery Sector}

During the struggle era from 1942 to the end of 1949, the number of fishermen at Pekalongan Port declined, and more than $50 \%$ of boats and marine fishing equipment were destroyed. Therefore, with the return of the Government of the Republic of Indonesia, there was an opportunity to reform the former marine fishery cooperatives that had been disbanded. In relation to the fate of fishermen, at the national level there were plans to rehabilitate fishing gear and revamp fisherman organizations (Eddiwan, 1965: 51). In revamping the fisherman organization, an important change occurred. The cooperative members were previously limited to boat owners, then starting in 1953, the membership was extended to all fishermen who participated in the production process. This decision changed substantially for the cooperative members, which was only from one element of the boat owner and then it also had to involve all elements in the production activities.

The decision to implement the expansion of democracy by accepting fishermen who only provided their strength to be the cooperative members in some regions was well received, but in other regions the expansion of democracy was difficult. There was a less enthusiastic reaction from the local communities at Pekalongan Port to the expansion of fisherman cooperatives as no sufficient sources were provided, bearing in mind that fishing activities in this area were still part of Mino Sojo Wonokerto Sea Fishery Cooperative activities in Pekalongan Regency. The objections from the employers due to the expansion of cooperative democracy was detrimental to their interests, specifically the attempt to be open and an obligation to submit some of their profits to the cooperative. Therefore, it was natural that some employers objected to the expansion of cooperative members. This group was then accused by the cooperative activists as a group that had not yet realized the purpose of the decision to expand democratic cooperative members in depth (Eddiwan, 1965: 51).

In 1953, an idea also emerged at a supra-local level that was quite important in the form of a fisherman resolution of which the contents demanded the government to form a separate Fisheries Department. The idea arose as a concern of fishermen due to the lack of government attention to the fishery problems. Although the resolution was adopted in 1953, it was only realized in June 1964, with the establishment of Department of Land-Sea Fisheries. The formation of a separate department did not really have an influence on fishery activities at the local level because the arrangement had not yet been carried out to a lower level, therefore, this department was liquidated into the Maritime Department (Eddiwan, 1965: 51). 
An interesting development in the fishery sector at Pekalongan Port was marked by the establishment of Makaryo Mino Sea Fishery Cooperative in 1962. It seemed that this local level development was related to the existence of an important policy set by the government in 1961, in the form of terminating fish import licenses from South Vietnam, Siam, Malaya and Singapore as it had been running in the past. The decision was made based on the political relations between nations, especially the neo-colonialist destruction project. The issuance of this decision would provide flexibility and freedom as well as protection of efforts to increase fish production by Indonesian fishermen themselves. However, in practice, stopping fish imports could not be fully implemented, because there were still illegal fish imports in the form of processed fish that were wrapped or put in cans.

Nevertheless, the fish import stop had resulted profit in the form of foreign exchange savings. Foreign exchange reserves were used to import modern fishing equipment, motorized engine; diesel, nylon mesh, nets and so on in order to boost domestic fish production. The policy directly affected the development and increase in fish production by Indonesian fishermen (Gemah Ripah No. 9, 1970: 14-22). Politically, the basic policy was the implementation of the self-reliance principles in the field of economics, where all efforts were based on their own abilities. The self-reliance principle aimed at the main implementation of TRISAKTI TAVIP, namely sovereignty in politics, self-reliance in economy, and personality in culture. In the field of fisheries, it had the aim of increasing the standard of living and life of fishermen, increasing food manufacturers, especially fish, and making fisheries as a source of business to generate foreign exchange (Eddiwan, 1965: 12).

In line with the implementation of the self-reliance principle in meeting the needs for fish, the Central Java Province made a regulation stipulating that all wet fish caught must be collected at a designated place for auction sale. Thus, there would be open fish marketing competition which would benefit the producer fishermen. The auction was organized by the existing fishing cooperatives. The purpose of granting authority to the cooperative as the auctioneer was to make the fishermen free from the money lenders or loan sharks who harmed the fishermen with the high interest burden and limited the fishermen freedom to sell to other seller, unlike before there was no cooperative, (Gemah Ripah No. 1, 1963: 21-25).

Nevertheless, the fishery cooperative policy which aimed to improve the fishermen welfare in its implementation was dealing with the previous system. Due to the economic actors in the fishery sectors as well as the fishermen who were engaged in a long and deeprooted ijon system (in which the the fish buyer/traders determine the fish price outside the fish market), it was difficult to be able to accept changes with the cooperative model just like that. Meanwhile, in order to achieve their goals as a means to improve the fisherman welfare, the fishery cooperatives still faced several difficulties, including: (1). The auction business was still limited to selling fish at landing sites, while processing and selling of the processed products were still controlled by the fish merchants. (2). The business of fishing equipment and daily needs of fishermen had not been obtained directly from the government but through so many channels outside the fisherman organization, so the prices of these items became very high. (3). Fisherman credit business was strictly limited both in the number of people who got credit and the amount of money. (4). Fisherman welfare effort was still in development stage and regulated locally. (5). The number of fishermen who were fishery cooperative organization members were only around $25 \%$. (6). In areas where there were no Fishery Cooperative, the production of processing and trading of captured fishes was controlled by fish merchants/money lenders. (7). Bond in the form of ijon was still rampant in many fishery areas (Gemah Ripah No. 1, 1963: 21-25).

The fish auction implementation arrangement by the cooperative was still for wet fish only. As for the marketing of salted fish, it was still largely controlled by a small group of Chinese ethnic merchants. Pekalongan communities called it a Chinese Kongsi. We could get an idea of the network and the dominance of the salted fish trade by a group of Chinese 
people by looking at the conditions at the supra-local level. The large scale of Chinese organization activities in the fishery sector could be compared to the Dutch company called The Big Five. The trading activities carried out by The Big Five could not match the scale of the salted fish trade by China which was incorporated in Ek Hoo Goan. This statement implied that the combined Chinese companies had undoubtedly carried out such a large trading activity with a wide marketing area. Even the Ek Hoo Goan business group was referred to as the "salted fish dynasty" which raked in the wealth of the Indonesian fishing communities, and it was due to the policy of the Dutch colonial government in the past which gave monopoly rights to import fish and domestic fish trade through the regional auction system. Various facilities and protection were given to Chinese ethnic merchants, therefore, the Indonesian people had difficulty in starting businesses in the salted fish marketing. They ran their business freely and flexibly without regard to the interests of producer fishermen. Trading activities they were carried out ranged from fish import to the distribution to retailers in small cities that were controlled by the Chinese merchant network. In addition, the domestic fish procurement and catch fishermen up to small retailers were also under their control. In the "Plan for Chinese Foreigner Replacement in the Field of Fishery and Fishery Cooperative", it was stated that the business of Chinese businessmen in the fishery sector had expanded greatly from the production sector to the commerce covering the field of fishing, fishing supplies and fishing equipment, grocery supply, processing, local transportation, storage, inter-island trade, wholesalers, intermediate merchants to retailers, credit, as well as salt and ice supplies (IKPI, 1967: 7-8). The most important areas controlled by China, based on their business fields were: the production sector occurring in the east coast of North Sumatra, Bagansiapiapi, Bengkalis-Riau, the north coast of Lamongan, and Muncar in East Java, and throughout West Kalimantan. The domination in processing and storage occurred in North Sumatra, Riau, Jambi, South Sumatra, East Java, West Kalimantan and East Kalimantan. Meanwhile, commerce dominance in production areas occurred in North Sumatra-Riau, Jambi, South Sumatra, Greater Jakarta, West Java, Central Java, East Java, throughout Kalimantan, and South Sulawesi. In addition, the commerce dominance in the consumption area occurred in Jakarta Raya, West Java, Central Java and East Java (IKPI, 1967: 8).

These domination of power began to arouse opposition due to the development of political conditions that were anti-foreign dominance. The great name of Ek Hoa Goan in 1965, had to be changed to Indonesian Aquatic Product Business Association or Perapin, a name that clearly showed a nuance separated from the Chinese word. It was stated in Pasar Pagi Jakarta that the Ek Hoa Goan members consisted of 32 large traders, approximately five of whom were Indonesian citizens of Chinese descent, and the others were fully Chinese (IKPI, 1967: 9). The name change was not necessarily accompanied by a setback of their business in the salted fish trade sector. They absolutely would not undermine the network of their dominance easily. Therefore, the salted fish trade was still controlled by this group. To change the complex chain in the fish trade, a marketing approach was used [6].

Thus, the policy measures for stopping fish imports would be based more on the political aspects, so the operational implementation had not yet been fully realized. This was indicated by the statement that up to 1968 , Indonesia was still called an importing country in the field of needs for fish [7]. The fish import still existed due to the several conditions in the country, among others: (1). Indonesia, with its equipment, still had not have the technical-economic capability to increase production in a sufficient amount to meet the domestic needs (2). Infrastructure that could support the production increase both at sea, on the beach and on land had not been available yet. (3). In terms of trade, given that West Java was the largest consumer of salted fish, the salted fish supplies was more profitable if imported [7].

Until a quarter of a century since Indonesia's independence, the fishery sector had not experienced significant development. This was due to the fact that both the community and 
the government themselves only paid little attention to the development, the advancement of marine fisheries and the fishing communities. Judging from the budget provided annually by the government for the marine fishery sector, it was clear that there was less attention to the development and progress of marine fisheries [7]. As a result, the fishery production remained low and it was under intense scrutiny and ridicule, which stated that Indonesia was blessed with enormous fish resources, but they were wasted because over $80 \%$ of the fish died due to the old age. The statement was inseparable from the existing conditions that until 1966 the potential for exploited fishery deposits was only 13\%, where the demersal potential of $5,500,000$ tons/year was only utilized by 720,000 tons/year. The low utilization occurred because $98 \%$ of fish production were produced by the local fisheries who worked with the simple and less effective tools [7].

\subsection{Policies on Foreign Capital in the Fishery Sector.}

In relation to foreign capital for the fishing business, Pekalongan was one of closed areas for foreign investment. As the policy of the Director General of Marine Wealth Management which aimed to protect local fishermen, it was determined the areas that should not be opened for foreign investment in the field of fishing, and it was because these areas had been used as collateral for local fisheries, among others were Bagansiapiapi waters extending to the northern waters around Jambi, South Sumatra, West Java, Central Java and East Java. It also covered the whole waters within a distance of 3 to 5 miles from the coast [7]. Therefore, the orientation of foreign investment was actually aimed at waters outside the areas that had been determined. However, as a discussion of the local supra, the foreign investment sector was important because since the enactment of Law No. 1/1967 on Foreign Direct Investment, there was a large-scale national fishery business pattern which in practice had led to deviations causing intervention with the local fishery business activities.

In line with the enactment of the Law on Foreign Direct Investment, all the facilities, flexibility and ease provided actually drew the attention of foreign capital on the fishery sector in Indonesia. The participation of foreign capital had opened a new chapter in national economic development and the history of Indonesian marine fishery development. Foreign capital seemed attracted to Indonesian marine resources which they considered as having enough potential to provide benefits. Therefore, in later developments, many foreign companies entered into cooperation with Indonesia. With the issuance of permits for foreign investors, the inland waters and Indonesian marine resources would be opened for foreign companies [7].

Foreign Direct Investment received exceptional attention. In 1967, there were already 19 foreign companies who wanted to invest their modal in Indonesia. From this number, six of them had received approval from the government, two companies were engaged in pearl farming, and four were engaged in catching tuna, shrimp and other fish. For example, PT Indonesia Pearl Co. which had collaborated with Fuyi Pearl Enterprise, Japan was engaged in the field of pearl and started working since 1965. In 1966, this company could export 6,308 half round pearls to Japan. In 1967 in the first quarter, it was exported 4,390 half round pearls, and in the second quarter exported 1,500 half round pearls and 46 round pearls. The classification of the level of cooperation project realization on the basis of foreign investment that had received the approval of four Acting President Officers were PT Cara-Cara Ambon, in cooperation with Arafura Pearl Co. Ltd, Toyo Menka Kaisah Ltd Japan, Faincon Incorporated, Philipina, PT Mina Djakarta in cooperation with The Gulf Fisheries Co. Kuwait-The International Fisheries USA. Then four foreign investors were still in the assessment of the technical team, eight foreign capitals had received principle approval from the Ministry of Maritime and were still completing the application requirements and draft 
agreement, 11 businessmen were in the application plan, and there were six national businessmen who would work together with foreign businessmen [5].

\subsection{Policy of Fishing Gear Use to Trawl Elimination.}

Decree of the Mayor of Pekalongan Municipality No. 623.4/81/1980 dated September 16 on the formation of Trawl Net Elimination Executive Team was the result of a long and tiered process. To understand these local policies, it was necessary to conduct a search of the policies that occurred before on a higher scale. The competition between fishermen who used simple fishing gear on a small scale and fishermen with advanced fishing gear in a large scale had caused losses to the small fishermen. Therefore, regulation and restriction on the operation of ships and fishing gear were issued as outlined in the Decree of the Minister of Agriculture No. 01/Kpts/Um/1/1975. Regarding the implementation in the field, supervision could not be carried out completely, causing violations in the use of tools and operating areas. This had caused unrest so that clashes between large fishermen and small fishermen occurred in various places. This condition had become the basis for the issuance of a decree which prohibited the operation of trawl net, as contained in Decree of the President of the Republic of Indonesia No. 39 of 1980 dated July 1, 1980 [4]. This Presidential Decree was then followed up with the Decree of Minister of Agriculture No. 503/Kpts/Um/1980 dated July 19, 1980 on Steps for Implementing the First Stage of Trawl Net Elimination. For Central Java Province, this provision was followed up with the Decree of the Governor of the Central Java No. 523.4/200/1980 on the Formation of Organizing Committee for the Transfer of ExFishing Trawlers in Central Java Province, dated September 9, 1980.

The regulations referred to were in the Decree of the Minister of Agriculture No. 01/Kpts/Um/1/1975 dated January 2, 1975, on the Development of Resource Preservation in the Indonesian Fishery Resources, in the form of restrictions and controls. Restrictions were carried out in the form of: (1) Closure of certain marine waters for one, some or all types of fishing activities. (2) Closure of certain seasons for some or all fishing areas for one, some or all types of fishing activities.

Then the fishing activity control was in the form of: (1) Determination of type, size and number of vessel to operate. (2) Determination of the width of net and other types of fishing equipment. (3) Determination of the catch quota. These provisions were followed up with the issuance of Decree of the Minister of Agriculture No. 607/Kpts/Um/9/1976 dated September 30, 1976 on Fishing Lane, which determined the details as follows: (1) Fishing lane I, was coastal waters 3 miles wide in the sea measured from the lowest point at low tide. (2) Fishing lane II, was waters 4 miles wide which were measured from the outside line of fishing lane I. (3) Fishing lane III, was waters as wide as 5 nautical miles measured from the outline of fishing lane II, and (4) Fishing lane IV, was the waters outside fishing lane III.

\subsection{Implementation of Trawl Elimination.}

As a follow-up to the implementation of Presidential Decree 39/1980 on the elimination of trawl net, in Central Java after the Instructions for Execution of Ex-Fishing Trawler Transfer by the Minister of Agriculture, Minister of Home Affairs, Minister of Trade and Cooperatives as stated in a Joint Letter dated August 28, 1980, Executing Committee for of Ex-Fishing Trawler Transfer in Central Java Province was formed. The task of the Level I Region (Panda I) Committee was to register fishing trawlers, determine vessel price transactions, plan and establish Village Unit Cooperative (KUD) that would receive vessels, receive vessel transfer from their owners and submit them to KUD, and provide guidance to KUD that would receive the vessel, both concerning changes in vessel equipment and the replacement of fishing gear. This decision was made in Semarang on September 9, 1980, or about three weeks before the 
first phase of trawl elimination was carried out. The structure of the organizing committee membership was a Chairman and concurrently a member of Assistant II Central Java Regional Secretary I, Secretary concurrently a member of the Head of the Provincial Fishery Agency, with members of the Head of Economic Bureau, Head of Legal Bureau, Head of Cooperative Regional Office, Head of Director General of Budget, Head of BRI Regional Office, Semarang Harbormaster, Cilacap Harbormaster, Semarang Maritime Security Task Force and Cilacap Maritime Security Task Force (Decree of Central Java Governor No. 523.201/1980).

Based on the Decree of the Central Java Governor dated September 9, 1980 No. 523.4/201/1980 on the Formation of the Executive Team for the Decree of the President of the Republic of Indonesia No. 39 of 1980, the Mayor of Pekalongan Municipality followed up with Decree No. 523.4/81/1980, dated September 16, 1980, which formed the Executive Team for Trawl Elimination of Pekalongan Municipality Level II Region (Panda II). The task of Panda II was to accommodate, handle and settle matters beyond the transfer of ex-fishing trawlers which included increasing fishery production, employment, increasing skills, and financing. The Head of the committee was the Secretary of Municipality, Secretary: Head of Fishery Service, with members: Head of Economy Section, Head of Finance, Head of Legal and Organization and Governance Division, Head of Cooperative Office, Head of Directorate General of Protection, Head of Directorate General of Community Development, Head of Bank Rakyat Indonesia of Pekalongan branch, Head of Pekalongan Archipelago Fishing Port, Head of Harbormaster, Commander of Pekalongan Water and Air Police, Head of Pekalongan Fishery Cooperative. The Level II Committee was formed about one week after the formation of the Level I Committee in Central Java, or two weeks before the implementation of trawl elimination. Even though the Level II Political and Social Affairs Section was not included in the committee for trawl elimination, but for this purpose there was an interesting information from a data absorption check list made by the Social and Political Office of Pekalongan Municipality. The check list consisted of 11 questions, with 34 items, which were confidential. The main points of the report in the check list related to reports that of 91 fishing trawlers in Pekalongan Municipality, 80 vessels obtained permits from the province, three vessels obtained permits from the central government, and eight did not have permits. Of the 91 vessels, 54 were built before 1975, and 34 were built after 1975, and three vessels were not identified. As for the alternatives, they were as follows: (1). Nothing was registered to be transferred to the government, because the price was deemed inappropriate (too low). (2) Nothing was moved to other areas. (3) Almost all were transformed using other fishing gear where the realization awaited the credit from banks. (4) There were owners who took other alternatives by dismantling the engine.

Based on the checklist, there were also reports of disappointment from some fishing trawler owners regarding the issuance of Presidential Decree 39/1980 because they still had unpaid loans. Moreover, the crew members of ex-fishing trawlers also complained about the transfer as the profit sharing decreased. The operation of fishing trawlers was enough with six to eight crew members, but after using purse seine, purse seine, it would take 25 to 30 crew members. Meanwhile, the small fishermen who did not have and did not use trawl gave enthusiastic responses. For small-traditional fishermen, the trawl elimination policy collectively encouraged their desire to borrow money from banks to make motorboats which cost more or less three to three and a half million rupiahs. As the result of trawl elimination, around 645 fishermen lost their job. Even so, the anxiety of fishermen was not obvious because many immediately changed to mini purse seine and outboard motors. The difficulty faced was the change of trawl captain who was then forced to become a purse seine crew member. To start work immediately, it was recommended for the workers to move to the purse seine vessel (202-212). 


\section{Conclusions}

From the discussion above, the conclusions of the problem in this research are: first, the concept of Fishery Self-Reliance policy which aims to meet their own needs and stop the imports, is more political in its implementation when dealing with the longstanding practice of Chinese ethnic business groups. Second, the implementation of FDI policy in the fishery sector has succeeded in increasing the fish catch, but it forces the fishing business activities by local fishermen. Third, the culmination of the urgency of traditional small fishermen by businessmen with modern tools, is by implementing trawl elimination. In the implementation of trawl elimination, it cannot be separated from the political nuances

\section{References}

[1]. D.H. Chusing, The Provident Sea. Cambrige University Press (1988).

[2]. Masyhuri, Menyisir Pantai Utara. Yogyakarta. Yayasan Pustakan Nusantara (1996).

[3]. F. A. Mc. Evoy. The Fishermen's Problem, Economy and Law in The California Fisheries, 1850-1980. New York-Cambrige University, (1986).

[4]. Mohammad bin Mohd Raduan, Arief, Dari Pemungutan Tripang ke Penundaan Udang: Sejarah perkembangan perusahaan perikanan di Borneo Utara 1750-1990. Kuala Lumpur, Penerbit Universiti Malaya, (1995).

[5]. Laporan Departemen Maritim (1967).

[6]. Laporan Tahunan Dinas Perikanan Jawa Tengah Tahun (1971-1972).

[7]. Majalah Gemah Ripah, No 1 tahun (1970). 